\title{
INFECȚIA CU HELICOBACTER PYLORI FAVORIZEAZĂ PREZENȚA GIARDIA LAMBLIA ÎN MUCOASA GASTRICĂ - PREZENTARE DE CAZ
}

\author{
Meliț Lorena Elena ${ }^{1,3}$, Mărginean Cristina Oana ${ }^{1,3}$, Mocan Simona², \\ Suciu Nicoleta ${ }^{3}$, Mărginean Maria Oana ${ }^{3}$ \\ ${ }^{1}$ Clinica Pediatrie 1 Târgu Mureș \\ ${ }^{2}$ Departamentul de Anatomie Patologică Târgu Mureș \\ ${ }^{3}$ Universitatea de Medicină și Farmacie Târgu Mureș
}

\begin{abstract}
REZUMAT
Helicobacter pylori și Giardia lamblia sunt răspândite în întreaga lume. Helicobacter pylori este un factor favorizant pentru prezența Giardia lamblia în stomac datorită neutralizării pH-ului gastric prin secreția de urează. Prezentăm cazul unui copil în vârstă de 5 ani, cu simptome gastro-intestinale intermitente în antecedentele personale patologice recente, care s-a internat în clinica Pediatrie 1 Târgu Mureș pentru dureri abdominale, grețuri, inapetență și hematemeză. Endoscopia digestivă superioară a evidențiat multiple sufuziuni hemoragice ale mucoasei gastrice, iar examenul histopatologic al mucoasei gastrice antrale a identificat coexistența infecției cu Helicobacter pylori și Giardia lamblia. Evoluția pacientului a fost favorabilă sub terapia de eradicare a infectiei cu Helicobacter pylori și tratamentul antiparazitar administrat, endoscopia de control arătând o mucoasă fără modificări vizibile macroscopic, iar reevaluare histopatologică evidențiind modificări regenerative ale mucoasei gastrice. Particularitatea cazului este reprezentată de identificarea prezenței parazitozei cu Giardia lamblia în mucoasa gastrică, mediu fiziologic acid, alcalinizat de ureaza secretată de Helicobacter pylori, asigurând astfel condiții favorabile dezvoltării acestui parazit la un copil în vârstă de 5 ani, dintr-un mediu socio-economic favorabil, cu simptome gastro-intestinale intermitente în antecedentele personale patologice recente.
\end{abstract}

Cuvinte cheie: Helicobacter pylori, gastrită, Giardia lamblia, copil

\section{INTRODUCERE}

Helicobacter pylori este o bacterie gramnegativă, flagelată, care colonizează mucoasa gastrică ducând la inflamația acesteia, cu posibilitate de cronicizare, ulcer sau chiar cancer gastric (1). Această bacterie cauzează cea mai frecventă infecție a speciei umane, fiind răspândită în întreaga lume și putând apărea la orice vârstă (2). Simptomele acestei infecții pot include durere abdominală, vărsături, inapetență, însă în multe cazuri aceasta este asimptomatică. Giardia lamblia, cunoscută și sub numele de Giardia intestinalis sau Giardia duodenalis, este un protozoar flagelat, care afectează mai ales copiii. Simptomele provocate de acest parazit pot fi reprezentate de diaree cronică, durere abdominală, inapetență, însă acestea pot lipsi la un număr mare de pacienți (3). Astfel că în cazul pacienților asimptomatici, această infecție se poate croniciza, aceștia constituind rezervoare de transmitere ale acestui protozoar. Giardia lamblia este adesea întâlnită în mucoasa duodenală, jejun și ileon, fiind rar observată în mucoasa gastrică sau cea colonică (4). Conform celor menționate anterior, se poate observa că 
cele 2 microorganisme prezintă multe caracteristici comune, precum frecvența crescută, lipsa simptomelor clinice în majoritatea cazurilor, și chiar posibilitatea de cronicizare. Deși prezența Giardia lamblia în stomac este în condiții fiziologice teoretic imposibilă dat fiind faptul că acest parazit nu supraviețuiește în mediul acid al stomacului, se pare că infecția cu Helicobacter pylori este un factor de risc pentru apariţia și supraviețuirea acestui parazit în stomac (5). Mecanismul fiziopatologic care explică favorizarea prezența acestui parazit în mucoasa gastrică este cantitatea mare de urează secretată de către Helicobacter pylori, care duce la creșterea pH-ului din stomac (4). Această enzimă reprezintă un mecanism adaptativ al Helicobacter pylori prin care ureea plasmatică secretată în stomac este degradată în ioni de amoniu, neutralizând mediul acid din stomac și protejând astfel bacteria de distrucția provocată de acesta (2). Metodele de diagnostic ale acestor două microorganisme pot consta în teste serologice pentru Helicobacter pylori (prezența anticorpilor anti-Helicobacter pylori în sânge), examinări din materiile fecale atât pentru Helicobacter pylori, cât și pentru Giardia lamblia (detectare antigen sau examen coproparazitologic. Cu toate acestea prezența Giardia lamblia în stomac poate fi identificată doar prin examen microscopic al piesei de biopsie recoltate prin endoscopie digestivă superioară. Tratamentul constă în măsuri de igienă riguroase, antibioterapie pentru eradicarea Helicobacter pylori și tratament antiparazitar pentru Giardia lamblia.

\section{PREZENTARE DE CAZ}

Prezentăm cazul unui pacient, în vârstă de 5 ani și 2 luni, care s-a internat în Clinica Pediatrie 1 Târgu Mureș deoarece a prezentat 6 vărsături, inițial cu striuri sanguinolente, iar ulterior cu sânge proaspăt, cu debut de aproximativ 12 ore, asociind de asemenea grețuri, inapetență și dureri abdominale. Din antecedentele personale patologice a reieșit că pacientul a acuzat intermitent simptome sugestive pentru o patologie gastro-intestinală (grețuri, vărsături, dureri abdominale), motive pentru care a urmat tratament cu Debridat și Nexium, și de asemenea în urmă cu aproximativ 3 săptămâni anterior internării a prezentat un episod de infecție acută a căilor aeriene superioare pentru care a urmat tratament antibiotic timp de 7 zile. Pacientul provenea dintr-un mediu socio-economic mediu, cu condiții bune de viață. Examenul obiectiv efectuat în momentul internării a evidențiat următoarele elemente patologice: stare generală influențată, tegumente palide, faringe hiperemic, amigdale hipertrofice, cu depozite purulente, abdomen suplu, elastic, dureros spontan și la

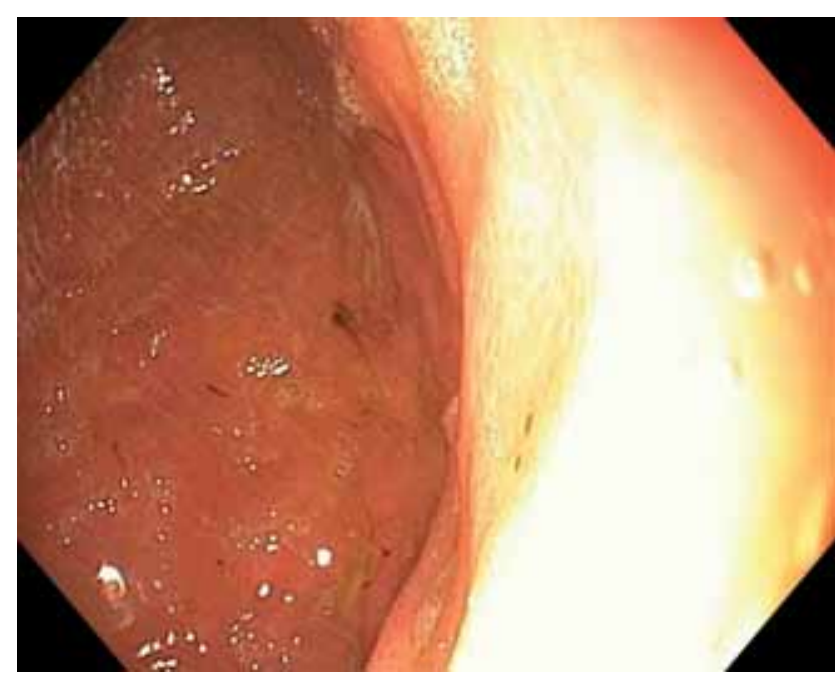

Figura 1. Aspect macroscopic al mucoasei gastrice corporeale

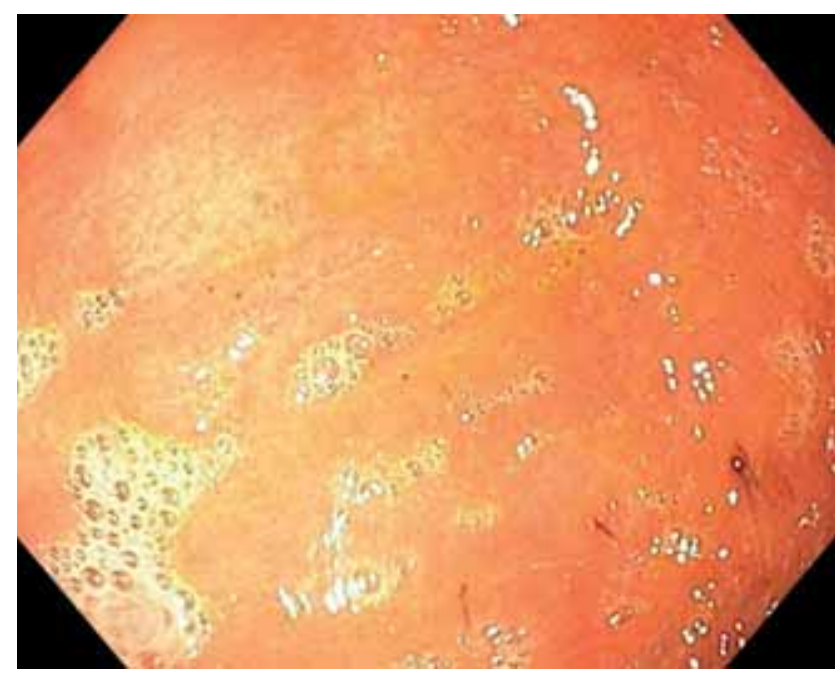

Figura 2. Aspect macroscopic al mucoasei gastrice antrale 
palpare superficială și profundă în epigatru, G: $20.5 \mathrm{~kg}$.

Hemoleucograma efectuată în momentul internării a evidențiat leucocitoză $(17.300 / \mu \mathrm{l}) \mathrm{cu}$

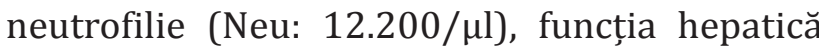
și renală în limite normale, precum și coagulograma. În a doua zi de internare, am efectuat de asemenea PCR, VSH, frotiu periferic și ecografie abdominală, însă fără a pune în evidență elemente patologice. Aspectul macroscopic al mucoasei gastrice observat în timpul endoscopiei digestive superioare, efectuată de asemenea în a doua zi de internare, a fost cu multiple sufuziuni hemoragice (Fig. 1 și 2). Am recoltat, de asemenea fragmente de biopsie din mucoasa antrală și corporeală în vederea efectuării examenului histopatologic.

Astfel, luând în considerare elementele patologice evidențiate de examenul obiectiv, analizele de laborator și aspecul endoscopic al mucoasei gastrice, am stabilit următoarele diagnostice: gastrită acută hemoragică și angină acută pultacee, motive pentru care am administrat tratament antibiotic timp de 5 zile (Axetine 2x 1 g/zi i.v.), inhibitor de pompă protonică (Controloc 20 $\mathrm{mg} / \mathrm{zi}$ ) și antiemetic intravenos (Metoclopramid $3 \times 3 \mathrm{mg} / z i$ i.v.). Evoluția pe parcursul internării a fost favorabilă, pacientul externându-se după 5 zile de internare cu următoarele recomandări: regim dietetic corespunzător patologiei actuale, cu evitarea alimentelor condimentate, a grăsimilor, alimentelor prăjite, a fructelor și legumelor proaspete, a sucurilor, de preferat a se consuma alimentele fierte, cu continuarea tratamentului cu inhibitor de pompă protonică per oral timp de o lună.

Rezultatul examenului patologic, la aproximativ o săptămână de la externare a identificat gastrită

Astfel că pacientului i-a fost recomandată terapia de eradicare a infecției cu Helicobacter pylori cu Amoxicilină (2x 500 mg/zi) și Claritromicină (2x $150 \mathrm{mg} / \mathrm{zi})$ timp de 14 zile, tratament antiparazitar cu albendazol (400 mg în

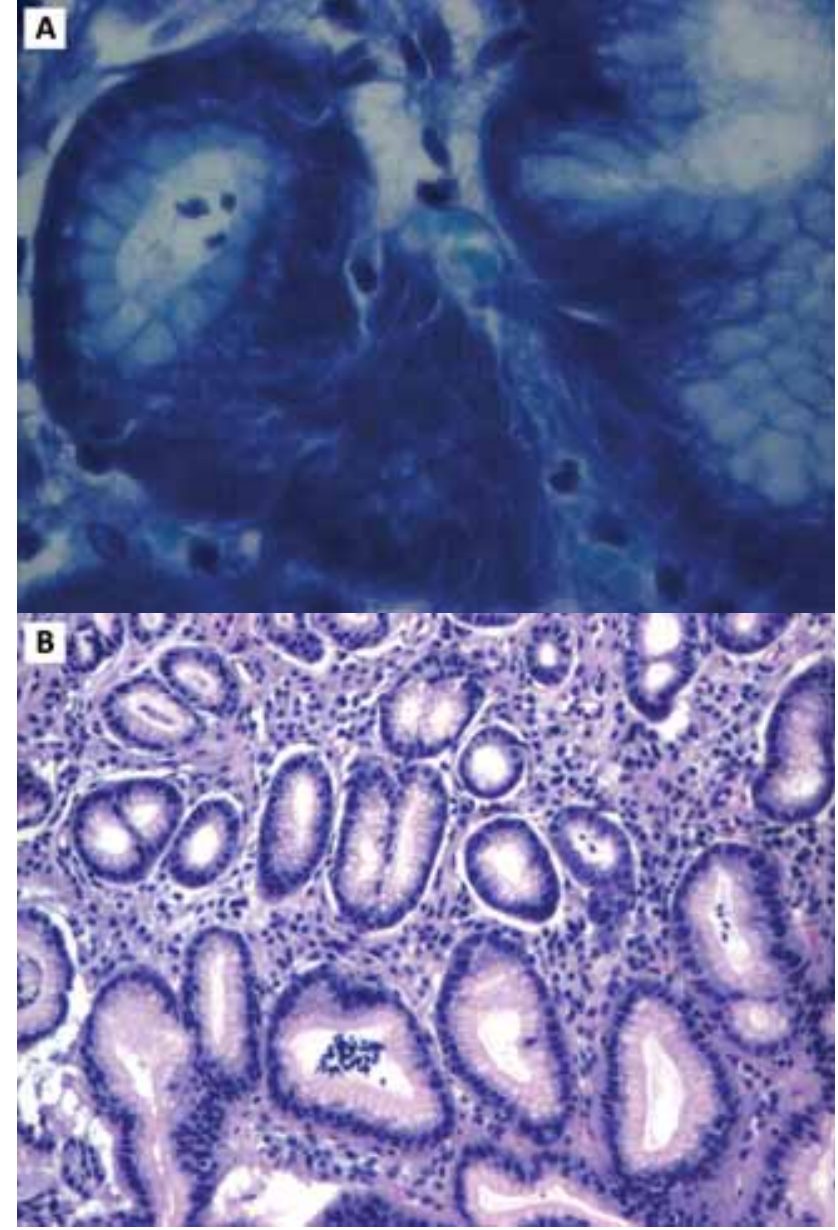

Figura 3. Aspect histopatologic al Helicobacter pylori și Giardia lamblia în mucoasa gastrică ( $A$ - colorație Giemsa, B - Hematoxilină-eozină)

doză unică, repetată după 7 zile), continuarea tratamentului cu inhibitor de pompă protonică timp de o lună, și reevaluare endoscopică după terminarea tratamentului. Endoscopia efectuată după aproximativ o lună a arătat un aspect macroscopic normal al mucoasei gastrice, iar rezultatul examenului histopatologic a evidențiat modificări regenerative ale mucoasei gastrice.

Particularitatea cazului este reprezentată de identificarea prezenței parazitozei cu Giardia lamblia în mucoasa gastrică, mediu fiziologic acid, alcalinizat de ureaza secretată de Helicobacter pylori, asigurând astfel condiții favorabile dezvoltării acestui parazit la un copil în vârstă de 5 ani, dintr-un mediu socio-economic favorabil, cu simptome gastro-intestinale intermitente în antecedentele personale patologice recente. 


\section{DISCUȚII}

Infecția cu Helicobacter pylori este răspândită în întreaga lume, estimându-se că aproximativ 50\% din populația globului este infectată cu această bacterie (2). Totuși, se pare că această infecția depinde de nivelul de dezvoltare socioeconomic, mai ales în cazul copiilor. Astfel, în tările dezvoltate, cum ar Statele Unite, această bacterie este rar întâlnită la copii (2). Pe de altă parte, în țările în curs de dezvoltare, prevalența acestei infecții la copii poate atinge procente de 82-92\% (6). Infecția cu Giardia lamblia este una din cele mai frecvente la copii, depinzând de asemenea de nivelul socio-economic. Astfel că dacă incidența acesteia în tările dezvoltate este între 2-5\%, aceasta poate ajunge până la 20-30\% în țările în curs de dezvoltare (7). Cu toate că pacientul nostru provenea dintr-un mediu socioeconomic favorabil, cu condiții bune de viață, a fost diagnosticat cu prezența co-infecției gastrice cu Helicobacter pylori și Giardia lamblia. Ambele microorganisme pot produce simptome gastro-intestinale precum durere abdominală, inapetență, vărsături sau diaree, însă aceste infecții pot fi și asimptomatice, putându-se croniciza. Astfel că un studiu efectuat pe 844 de copii sănătoși din Portugalia, a identificat prezența infecției cu Giardia lamblia într-un procent de $6.8 \%$ din cazuri (8). Același studiu a arătat prezența Helicobacter pylori la 25 de copii din cei 57 depistați cu Giardia lamblia, prin detectarea antigenului Helicobacter pylori din materiile fecale (8). Un alt studiu efectuat pe 427 de copii asimptomatici din Uganda a subliniat că $20 \%$ din aceștia erau purtători de Giardia, identificând corelație pozitivă între acest parazit și infecția cu Helicobacter pylori (9). În cazul prezentat mai sus, am stabilit diagnosticul de co-infecție prin identificarea celor două microorganisme la examenul histopatologic din mucoasa gastrică. Cronicizarea infecției cu Giardia lamblia poate duce la scădere ponderală și retard de creștere (10), pe când cea cu Helicobacter pylori poate provoca ulcer peptic, hemoragie digestivă, sau chiar cancer gastric (1). Wigren a descris un caz de infecție a mucoasei gastrice cu Giardia lamblia la un pacient în vârstă de 56 ani, cu rezecție gastrică în antecedente, care s-a asociat cu gastrită cronică activă determinată de Helicobacter pylori (11), similar cazului nostru. Un alt studiu, mai recent, efectuat pe 160 de pacienți cu colecistită cronică asociată cu gastro-duodenită cronică, a evidențiat prezența Giardia lamblia în piesele bioptice din stomac în 29,09+/-6,12\% din cazuri, iar frecvența depistării Helicobacter pylori în mucoasa gastrică a fost de 98,18+/$1,8 \%$ din cazuri (12). Sabah a subliniat o asociere în 51,4\% din cazuri a infecției cu Helicobacter pylori și Giardia lamblia într-un studiu efectuat pe un lot de 206 adulți cu diferite simptome gastro-intestinale, pe când Eldash a identificat, întrun studiu caz-control pe 90 de pacienți cu dureri abdominale recurente și 90 de martori sănătoși, o incidență a co-infecției cu cele 2 microorganisme de aproximativ 40\% (13). Escobar-Pardo a subliniat și el o asociere între Helicobacter pylori și Giardia lamblia într-un studiu efectuat pe 245 de copii brazilieni (14). Cu toate că este clar stabilit faptul că Helicobacter pylori reprezintă un factor favorizant pentru prezența Giardia lamblia în stomac, există încă multiple date controversate, care vor constitui tema unor studii viitoare.

\section{CONCLUZII}

Giardia lamblia este un parazit rar întâlnit în mucoasa gastrică datorită faptului că supraviețuieste doar în mediu alcalin. Infecția cu Helicobacter pylori este un factor favorizant pentru prezența Giardia lablia în stomac prin neutralizarea ph-ului gastric datorită secreției crescute de urează. 